\section{India seeks tighter controls on germplasm}

[NEW DELHI] Lathyrus sativus is a hardy pulse crop that is immune to droughts, needs no fertilizer and is 25 per cent protein. But there is a drawback: regular consumption can cause paralysis, as it contains a neurotoxin.

Scientists at the Indian Agricultural Research Institute (IARI) in New Delhi have now bred a toxin-free variety that could wipe out protein malnutrition in poor countries. But when Australian researchers recently asked for a few seeds to check if they were really toxin-free, they were given only a few grams of powdered - not whole - seeds.

The Australians were also told that if they wanted to grow the crop, they must negotiate a deal. "We have become wise," says Suresh Sinha, former director of IARI. Sinha complains that in the 1980s, Australia took away chickpea strains without payment, grew them up at home, and then exported them "not only back to us but to the Middle East".

Sinha is one of those who believe that India, which had been treating germplasm as a common heritage and freely allowing outsiders to collect, needs to protect whatever germplasm has not already been taken. "If you want the grain amaranthus that once grew wild in the Himalayas, you now have to go to the University of California at Davis," says Hari Krishan Jain, another ex-director of IARI and a former consultant to the Food and Agricultural Organization.

According to Jain, the only Indian germplasm not sitting in US gene banks is "what is available in our forests". And even this gap is being filled through joint projects, such as a $\$ 300,000$ study on the management of biological diversity funded by the US Department of Agriculture at the Wildlife Institute of India in Dehra Dun.

In a country where political sensitivities still run deep over 'exploitation' by multinational corporations - much of it focused on such corporations' efforts to claim patent rights for extracts from plants of Indian origin, such as the high-profile dispute over the 'neem' tree (see Nature 377, 95; 1995) — many scientists nevertheless agree that the exchange of germplasm between countries is necessary to develop new varieties and improve food production.

"The United States used to tell us that germplasm is common heritage," says Jain. "But once biotechnology became interested in the 1980s, it dropped the heritage philosophy and called for patent protection."

India's current efforts to conserve its agro-biodiversity centre on the $\$ 20$ million national gene bank commissioned last year, with its network of ten regional stations and 30 active collection centres spread around

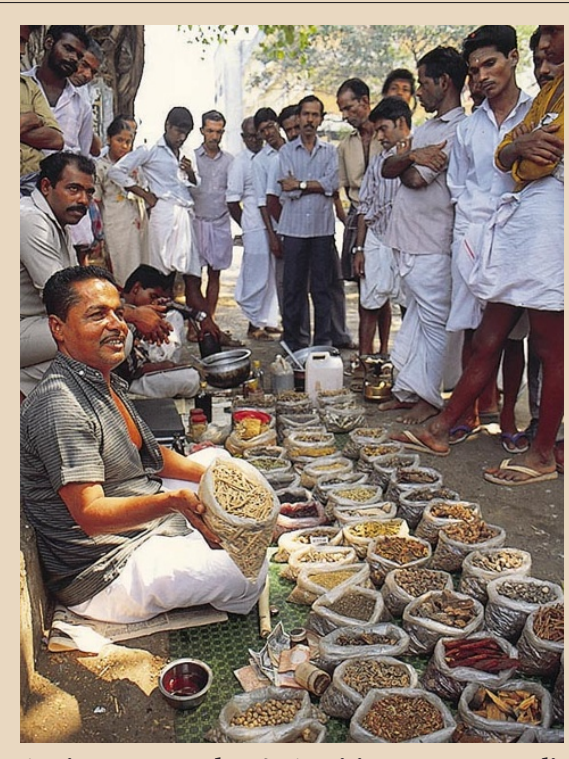

Ancient or modern? An itinerant ayurvedic vendor in Kerala State, India.

the country. Built with US funds, "it is the third biggest seed bank in the world with a capacity to store one million samples for several years", says P. L. Gautam, director of the National Bureau of Plant Genetic Resources (NBPGR), the nodal agency for plant exploration, conservation, germplasm import and export.

At present the bank has 167,236 base collections, and Gautam says he is trying to get back all its original germplasm from international gene banks. So far, only 9,000 samples have been returned at NBPGR's request. And none has yet been requested from the bank holding the largest collections from India - the US bank at Fort Collins in Colorado. But Rajendra Singh Paroda, director general of the Indian Council of Agricultural Research (ICAR), says he does not foresee a major problem in getting the germplasm back.

Paroda says the conservation of agrobiodiversity is at the top of ICAR's agenda, and that the export of germplasm will be regulated by legislation being drafted in accordance with the UN Convention on Biodiversity, which India ratified in 1994. The legislation will prohibit open access to the Indian gene bank by US seed companies — access that was allowed under a 1988 agreement with the United States.

The draft biodiversity legislation, which is designed to combat 'biopiracy' and has still to be approved by parliament, proposes to regulate access to the country's biological pharmaceutical companies. Indian scientists who transfer commercially exploitable research results to outsiders without official approval would be punished. K.S. Jayaraman resources by foreign researchers and
The NCI requires anyone who exploits its repository to involve the country of origin in the development of any derivative products, and to pay royalties that increase with the scale of exploitation. But in some places, Newman says, this is no longer enough. "We've stopped collecting in some countries because they wanted things that we just couldn't give," he says (see page 538).

In a bid to satisfy these new demands, three US bodies - the National Institutes of Health (NIH), the National Science Foundation and the US Agency for International Development (USAID) - established a programme in 1992 to build four-way partnerships between industry and science in both the United States and in the donor country.

Five of these International Co-operative Biodiversity Groups (ICBGs) have been established (although the USAID has withdrawn from the programme), each costing the US government about $\$ 500,000$ a year to run. "They have been very challenging to set up," says Josh Rosenthal, who runs the programme from NIH's Fogarty International Center (see page 539). "It is very novel terrain."

"The idea is that the groups should serve as models for how drug discovery could be done, while serving broader conservation goals," says Rosenthal. He adds that industrial corporations are ready to share costs with host countries and to pay royalties to them — but are not ready to make major, up-front investments to meet these conservation goals. "We'd like to see the private sector do it, but my sense is that that is not going to happen. Industry isn't interested in raising its budgets for natural products research."

\section{Synthetic alternatives}

Instead, industry is pursuing increasingly powerful techniques for developing drugs based on molecules that scientists can create for themselves in the laboratory, using new combinatorial chemistry techniques.

Until a few years ago, the in vitro screening of a given compound against a target was a time-consuming process that constrained the number of samples that the drug companies needed or wanted to test. The task was to select the most promising compounds for test. These were usually natural products.

Today, however, assays can be done 5,000 at a time in automated machines, and the sources of properly documented natural products can't keep up. Combinatorial chemists can use modern techniques to create arrays of thousands of slightly different molecules, ready to go into screening and, perhaps, feed the drug firms' insatiable appetite for a 'hit'.

At present, all these synthetic molecules are polymers. The understanding of structural biology doesn't allow for the creation of anything with such a novel structure as, say, Taxol, which consists of four intricately 